\title{
The impact of the food-based and nutrient-based standards on lunchtime food and drink provision and consumption in primary schools in England
}

\author{
Dalia Haroun, Clare Harper, Lesley Wood and Michael Nelson* \\ School Food Trust, 6th Floor - Sanctuary Buildings, Great Smith Street, London, SW IP 3BT, UK
}

Submitted 15 March 2010: Accepted 4 June 2010: First published online 12 August 2010

\begin{abstract}
Objective: To assess lunchtime provision of food and drink in English primary schools and to assess both choices and consumption of food and drink by pupils having school lunches. These findings were compared with similar data collected in 2005. Design: Cross-sectional data collected between February and April 2009. In each school, food and drink provision, including portion weights and number of portions of each item served at lunchtime, were recorded over five consecutive days. Caterers provided school lunchtime menus and recipes.

Setting: England.

Subjects: A random selection of 6696 pupils having school lunches in a nationally representative sample of 136 primary schools in England.

Results: Compared with 2005, schools in 2009 provided significantly more fruit, fruitbased desserts, vegetables and salad, water and fruit juice, and less ketchup, sauces and gravy, starchy foods cooked in fat, snacks and confectionery $(P<0 \cdot 01)$. Pupils were also making healthier choices, choosing an average of $2 \cdot 2$ portions of fruit and vegetables from their 'five a day', but about one-third to two-fifths of these were wasted.

Conclusions: Lunchtime food provision and consumption in primary schools have improved substantially since 2005, following the introduction of new standards for school food in 2008. However, improvements still need to be made to increase the $\mathrm{Fe}$ and $\mathrm{Zn}$ content and to decrease the $\mathrm{Na}$ content of recipes, and in encouraging pupils to eat more of the fruits and vegetables taken at lunchtime.
\end{abstract}

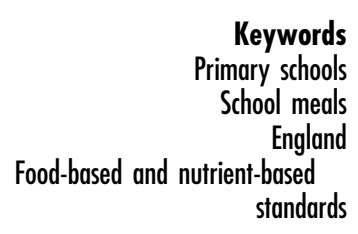

The prevalence of childhood obesity in the UK has increased substantially since 1995 , with $16 \cdot 5 \%$ of children aged 2-15 years reported to be obese (defined as BMI $>95$ th percentile of the 1990 UK reference population $)^{(1)}$. School meals play an important role in children's diet; lunches typically contribute between one-quarter and one-third of children's daily intake of energy and nutrients $^{(2)}$. In 2009 the take-up of school lunches in primary schools was $39 \cdot 3 \%{ }^{(3)}$, representing an average of 1636833 primary-school children having schools meals every day.

Improving the quality of school meals is vital for improving children's health, especially in the effort to decrease levels of obesity and future risks of related diseases such as diabetes and hypertension. Furthermore, improvements in diet may benefit children's concentration, behaviour and academic performance ${ }^{(4-6)}$. It is essential, therefore, that school meals provide sufficient energy and nutrients to support children's nutrition, growth and development, and academic achievement, and lay the foundations for healthy eating in adulthood.
In April 2001, the Department for Education and Skills introduced food-based standards (FBS) for school meals to improve their balance and nutritional quality ${ }^{(7)}$. A survey in 2005 of lunchtime food provision and consumption in primary schools in England showed that the nutritional profile of school lunches was poor; over half of pupils' lunches consisted of dishes high in fat, starchy food cooked in fat or oil (e.g. chips) and drinks containing sugar, and consumption of fruit and vegetables was below recommended levels ${ }^{(8)}$. In response to concerns about the poor quality of school meals and increasing levels of childhood obesity, the government established the School Meal Review Panel to revise guidelines for school meals and to set standards for the nutritional content of school lunches ${ }^{(9)}$. The panel proposed changes that would maximize the availability of healthier items such as fruit and water, prohibit or restrict foods or drinks high in salt, sugars and fat such as confectionery, crisps and high-sugar fizzy drinks, and limit the availability of deep-fried food from being served at school. 
From September 2008, catering provision in all primary schools in England was required to be fully compliant with the new FBS and nutrient-based standards (NBS) for school lunches ${ }^{(10-13)}$. Thirteen FBS are intended to increase access to healthier foods such as fruit, vegetables and bread, and to limit the availability of less healthy foods such as confectionery, snacks and high-sugar drinks. For example, at least one portion of fruit and one portion of vegetable must be provided at lunchtime for every pupil having a school lunch, and starchy food cooked in fat should not be provided more than three times per week across the school day. Fourteen NBS complement the FBS, ensuring that provision, for example, contains appropriate amounts of energy, adequate $\mathrm{Fe}$, and not too much fat, sugar or salt.

To assess the impact of the introduction of new school food standards, the School Food Trust carried out a survey of a nationally representative sample of primary schools in England to assess: (i) catering provision of food and drink at lunchtime; (ii) pupils' choices and consumption of food and drink at lunchtime (including packed lunches); (iii) the nutrient content of school lunches; and (iv) compliance of provision with the standards for school food. The findings, reported in the present paper, are compared with those from a similar survey carried out in $2005^{(8)}$. Findings on packed lunches will be reported separately.

\section{Methods}

\section{Sample}

In September 2008 a random sample of 290 primary schools in England with at least 100 pupils $^{(14)}$, stratified by region, school stage, school type and postcode, were approached and asked to take part in the study with the aim of achieving a representative sample of primary schools across England. Data from the previous survey in primary schools in England in 2005 indicated that 150 schools were sufficient in providing the variation across all the selection criteria, as required (such as school region); hence the aim was to replicate that in this survey ${ }^{(8)}$. Information sheets for both the head teacher and the caterer, along with school reply forms (confirming the school's consent), were collected. Of these, 139 schools (48\%) agreed to take part; 107 schools declined, six schools withdrew and thirty-eight schools did not respond. Three schools were excluded from the analyses because they served only packed lunches. The final sample included 136 schools spread across all nine government regions, with catering provision that matched patterns seen nationally ${ }^{(3)}$.

Schools included primary and middle-deemed primary schools in England. Community, Voluntary-Aided, VoluntaryControlled and Foundation Schools were included in the sample. Schools were excluded if they contained fewer than 100 pupils, if they served only packed lunches, or if they had taken part in the previous survey of Primary School Meals ${ }^{(8)}$ or the School Lunch and Behaviour Study in primary schools ${ }^{(4)}$.

One week before fieldwork commenced, participating schools were sent information sheets to send to all parents/guardians informing them about the survey and asking them to reply only if they did not wish their child to take part. A list of these students was made available to the fieldworkers on the first day of data collection in each school. Consent from students at the time of data collection was verbal. Fieldworkers received two days training on sampling and data collection methods, which included recording and weighing food and drink items provided at lunchtime, and recording information about what items pupils chose and ate at lunchtime.

Schools were visited at lunchtime on five consecutive days between February and April 2009. Each day, fieldworkers recorded: all items served at lunchtime; the number of portions and weights of each item provided; and the number of pupils catered for. Nine per cent of portion numbers and $3 \%$ of portion weights were missing, and these were subsequently imputed from within the data set. These most frequently related to drinks and condiments.

Each day, fieldworkers selected ten school lunch pupils and five packed lunch pupils using a random selection technique. Fieldworkers recorded pupil-level information (age, sex and school year) and described all items taken and eaten by pupils. At the end of lunch, all participating pupils returned their tray or lunch box to the fieldworkers, who weighed any leftover items individually. A total of 6696 children (3251 boys; 3341 girls; 104 sex not recorded) aged from 3 to 12 years had data on school lunch recorded. The large number of observations of school lunch food choices (over 38160 ) was sufficient to demonstrate differences in the amounts of foods chosen and eaten between pupils in different subgroups (by sex, age, year, school group, etc.).

Pupils who chose to have a second helping (0.3\%) were assumed to be taking half the weight of the first portion. Children who did not return their leftover items to be weighed were assumed to have consumed all their meal. Weight eaten was estimated by subtracting leftover weight from the portion weight determined for each item taken. In $0.05 \%$ of cases (spread across a variety of food groups) the value was negative; it was assumed for these items that none of that particular item was consumed.

Ethical approval was granted from Kings College London Ethical Committee.

\section{Data preparation}

The Food Standards Agency nutrient databank provided the energy and nutrient data on food composition ${ }^{(15)}$. School lunch items were categorised into one of twenty-two different food groups (see Appendix). To allow comparisons with data collected in 2005 , the 2005 data were re-coded to match the 2009 food group classification. 


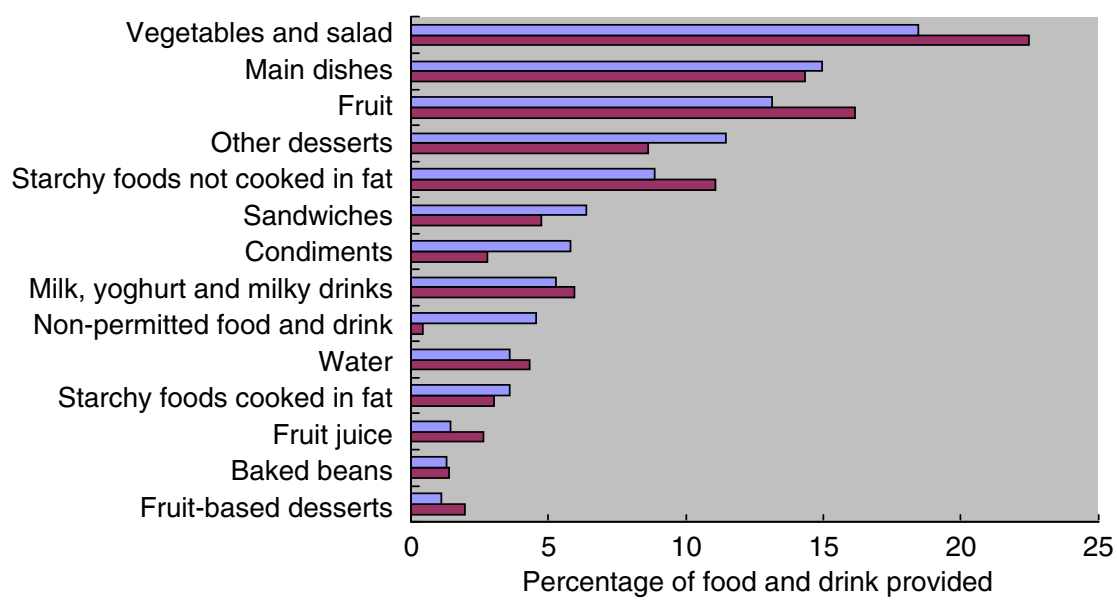

Fig. 1 Percentage of types of food and drink items provided by caterers at lunchtime, by food group, primary schools, England, $2005(\square)$ and $2009(\square)$. Each bar shows how many types of food or drink were provided in a given food group as a percentage of all items provided by the caterer at lunchtime. All differences were statistically significant at $P \leq 0 \cdot 01$ except for main dishes and baked beans. Vegetables and salad included raw and cooked vegetables (but do not reflect the contribution from vegetables in main dishes). Fruit-based desserts contained an average of $40 \%$ fruit. Base (schools): 2005, $n$ 151; $2009, n 136$

Compliance with the standards was assessed against published regulations ${ }^{(10)}$. Compliance with the FBS was analysed in two ways: planned provision and actual provision. Planned provision related to provision of food at lunchtime based on data provided from full menu cycles; actual provision related to direct observations of school lunch provision in schools over the five days of fieldwork. Standards which required assessment over two or three weeks, such as those for meat products and oily fish, could not be assessed in relation to actual provision. Compliance of school meals with the NBS was based on actual provision. Separate NBS are available for infants and juniors; hence these have been reported separately.

\section{Statistical analyses}

Data were analysed using the SPSS statistical software package version 15 (SPSS Inc, Chicago, IL, USA). The $\chi^{2}$ test was used to assess differences in food group availability between schools (e.g. by type of catering provider) or between years (2009 v. 2005). The independent-sample $t$ test was used to compare differences in nutrients taken or eaten by different groups of pupils (e.g. males $v$. females, infants $v$. juniors).

\section{Results}

\section{Food and drink provision at lunchtime}

Figure 1 compares food provision at lunchtime, $2009 v$. 2005 , by food group, as a percentage of all types of food/ drinks provided. Compared with 2005, schools in 2009 were providing significantly more vegetables and salad (4.0\%; $P<0 \cdot 001)$, fruit $(3 \cdot 0 \% ; P<0 \cdot 001)$, starchy foods not cooked in fat $(2 \cdot 2 \% ; P=0 \cdot 004)$, milk, yoghurt and milky drinks $(0 \cdot 7 \% ; P=0 \cdot 01)$, water $(0 \cdot 7 \% ; P=0 \cdot 001)$, fruit juice $(1 \cdot 2 \% ; P<0.001)$ and fruit-based desserts $(0.9 \%$; $P<0 \cdot 001)$. Conversely, schools in 2009 were providing significantly fewer desserts not containing fruit $(-2 \cdot 8 \%$; $P<0.001)$, condiments $(-3.0 \% ; P<0.001)$, starchy food cooked in fat $(-0.6 \% ; P=0.004)$ and non-permitted items such as savoury snacks and confectionery $(-4 \cdot 1 \%$; $P<0 \cdot 001)$. There were no statistically significant differences in the provision of main dishes $(0 \cdot 6 \% ; P=0 \cdot 1)$ or baked beans $(0 \cdot 1 \% ; P=0 \cdot 6)$ between 2005 and 2009 .

\section{Food and drink choices of pupils baving a scbool lunch}

Similar trends were seen in pupils' food selection following changes in food/drinks provision (Fig. 2). In 2009, 21.8\% more pupils took water, $14 \cdot 7 \%$ more took vegetables and salad, $9 \cdot 4 \%$ more took fruit juice, $8 \cdot 4 \%$ more took fruitbased dessert, $7 \cdot 2 \%$ more took starchy foods not cooked in fat, $6.5 \%$ more took fruit and $3.1 \%$ more took milk, yoghurt and milky drinks $(P<0 \cdot 001)$. In contrast, $3 \cdot 8 \%$ fewer pupils took other (non-fruit-based) desserts, $5 \cdot 9 \%$ fewer took condiments, $7 \cdot 2 \%$ fewer took starchy foods cooked in fat and $7 \cdot 1 \%$ fewer pupils took items from the non-permitted group at lunchtime $(P<0 \cdot 001)$.

Table 1 shows the percentage of pupils choosing food/ drinks items, and the average weights taken and eaten from each of the twenty-two food groups. Approximately $80 \%$ of pupils in 2009 were taking meat, poultry, fish and main dishes providing the main source of protein in the meal. Over half $(57 \cdot 1 \%)$ took vegetables (not including vegetables in mixed dishes) and almost a quarter (22.9\%) took salad. Just under $40 \%$ took fruit or a fruit-based dessert and $14 \cdot 8 \%$ took fruit juice. Over half of pupils $(51 \cdot 3 \%)$ had plain water to drink. Only $10.9 \%$ of pupils took meat products (sausages, burgers, sausage rolls, etc.), and less than $4 \%$ of pupils took either drinks high 


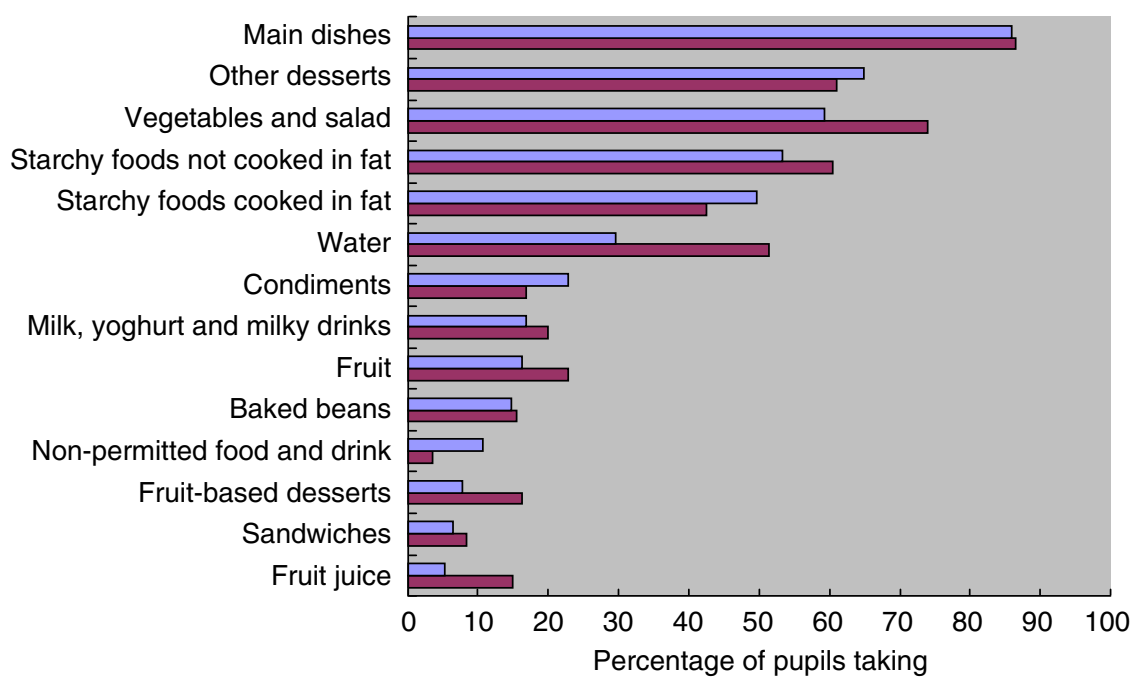

Fig. 2 Percentage of pupils having a school lunch who took specific items of food and drink, by food group, primary schools, England, $2005(\square)$ and 2009 ( $\square$ ). Each bar shows the percentage of pupils having a school lunch who took an item of food or drink from a specific food group. All differences were statistically significant at $P \leq 0.001$ except for main dishes and baked beans. Vegetables and salad included raw and cooked vegetables (but do not reflect the contribution from vegetables in main dishes). Fruit-based desserts contained an average of $40 \%$ fruit. Base (pupils): 2005, $n$ 7166; 2009, $n 6696$

Table 1 Percentage of pupils taking specific food and drink items, weight as taken, weight as eaten and wastage, by food group, primary schools, England, 2009

\begin{tabular}{|c|c|c|c|c|c|c|c|c|}
\hline \multirow[b]{3}{*}{ Food group } & \multirow{3}{*}{$\frac{\text { Pupils taking }}{\%}$} & \multicolumn{2}{|c|}{ Weight as taken } & \multicolumn{2}{|c|}{ Weight as eaten } & \multicolumn{3}{|c|}{ Plate wastage* } \\
\hline & & Mean & SD & Mean & SD & Mean & SD & \\
\hline & & g & g & g & g & g & g & $\%$ \\
\hline Meat, poultry, fish & $33 \cdot 1$ & $58 \cdot 7$ & $27 \cdot 7$ & $48 \cdot 5$ & $28 \cdot 6$ & $10 \cdot 6$ & $35 \cdot 4$ & $18 \cdot 9$ \\
\hline Meat product & $10 \cdot 9$ & $79 \cdot 8$ & $38 \cdot 0$ & $69 \cdot 5$ & $35 \cdot 4$ & $10 \cdot 5$ & $27 \cdot 3$ & $11 \cdot 3$ \\
\hline Protein \& carbohydrate & $9 \cdot 3$ & $113 \cdot 3$ & $52 \cdot 6$ & $86 \cdot 4$ & $52 \cdot 7$ & $28 \cdot 1$ & $35 \cdot 8$ & $24 \cdot 3$ \\
\hline Protein \& vegetable & $9 \cdot 3$ & $107 \cdot 1$ & $35 \cdot 2$ & $77 \cdot 6$ & $46 \cdot 1$ & $30 \cdot 5$ & $39 \cdot 1$ & $31 \cdot 0$ \\
\hline Protein, carbohydrate \& vegetable & $21 \cdot 4$ & $113 \cdot 6$ & $62 \cdot 9$ & $85 \cdot 0$ & $59 \cdot 9$ & $29 \cdot 6$ & $35 \cdot 1$ & $25 \cdot 1$ \\
\hline Protein other & $6 \cdot 6$ & $37 \cdot 2$ & $18 \cdot 5$ & $31 \cdot 5$ & $18 \cdot 7$ & $6 \cdot 0$ & $31 \cdot 5$ & $16 \cdot 4$ \\
\hline Carbohydrate \& vegetable & $5 \cdot 4$ & $101 \cdot 8$ & $52 \cdot 5$ & $69 \cdot 6$ & $51 \cdot 8$ & $33 \cdot 7$ & $43 \cdot 9$ & $34 \cdot 6$ \\
\hline Carbohydrate & $60 \cdot 4$ & $86 \cdot 0$ & $56 \cdot 3$ & $61 \cdot 5$ & $49 \cdot 6$ & $25 \cdot 7$ & $38 \cdot 1$ & $28 \cdot 3$ \\
\hline Starchy foods cooked in oil & $42 \cdot 4$ & $74 \cdot 0$ & $30 \cdot 7$ & $59 \cdot 1$ & $33 \cdot 7$ & $15 \cdot 4$ & $33 \cdot 0$ & $20 \cdot 6$ \\
\hline Vegetables & $57 \cdot 1$ & $60 \cdot 0$ & $27 \cdot 2$ & $39 \cdot 1$ & $28 \cdot 5$ & $22 \cdot 5$ & $45 \cdot 9$ & $40 \cdot 7$ \\
\hline Salad & $22 \cdot 9$ & $40 \cdot 8$ & $25 \cdot 1$ & $30 \cdot 3$ & $24 \cdot 5$ & $11 \cdot 6$ & $58 \cdot 2$ & $32 \cdot 6$ \\
\hline Baked beans & $15 \cdot 6$ & $85 \cdot 2$ & $22 \cdot 9$ & $74 \cdot 5$ & $27 \cdot 9$ & $11 \cdot 0$ & $23 \cdot \overline{4}$ & $13 \cdot 9$ \\
\hline Sandwiches & $8 \cdot 4$ & $84 \cdot 9$ & $55 \cdot 2$ & $66 \cdot 3$ & $52 \cdot 7$ & $19 \cdot 2$ & $41 \cdot 0$ & $27 \cdot 3$ \\
\hline Fruit & $22 \cdot 9$ & $80 \cdot 3$ & $43 \cdot \overline{7}$ & $56 \cdot 4$ & $42 \cdot 6$ & $25 \cdot 1$ & $49 \cdot 2$ & $32 \cdot 7$ \\
\hline Fruit-based dessert & $16 \cdot 2$ & $82 \cdot 9$ & $33 \cdot 3$ & $64 \cdot 9$ & $39 \cdot 6$ & $18 \cdot 8$ & $36 \cdot 8$ & $23 \cdot 8$ \\
\hline Other dessert \& dessert accompaniment & $61 \cdot 0$ & $85 \cdot 8$ & $52 \cdot 7$ & $74 \cdot 7$ & $52 \cdot 7$ & $11 \cdot 8$ & $29 \cdot 7$ & 14.9 \\
\hline Milk, yoghurt \& milky drinks & $20 \cdot 0$ & $134 \cdot 9$ & $52 \cdot 6$ & $110 \cdot 3$ & $56 \cdot 3$ & $24 \cdot 7$ & $27 \cdot 7$ & $17 \cdot 4$ \\
\hline Fruit juice & $14 \cdot 8$ & $132 \cdot 7$ & $48 \cdot 3$ & $114 \cdot 0$ & $52 \cdot 4$ & $19 \cdot 0$ & $26 \cdot 9$ & $14 \cdot 1$ \\
\hline Water & $51 \cdot 3$ & $124 \cdot 0$ & 30.5 & 93.6 & $47 \cdot 6$ & $31 \cdot 8$ & $40 \cdot 6$ & $26 \cdot 1$ \\
\hline Condiments & $16 \cdot 9$ & $48 \cdot 2$ & $34 \cdot 0$ & $44 \cdot 4$ & $33 \cdot 2$ & 3.9 & $28 \cdot 1$ & $10 \cdot 9$ \\
\hline Non-permitted drink & $3 \cdot 0$ & $145 \cdot 9$ & $29 \cdot 7$ & $123 \cdot 2$ & $47 \cdot 2$ & $22 \cdot 7$ & $27 \cdot 3$ & $15 \cdot 5$ \\
\hline Dessert containing confectionery & $0 \cdot 6$ & $48 \cdot 8$ & $21 \cdot 4$ & $43 \cdot 5$ & $23 \cdot 5$ & $5 \cdot 5$ & $22 \cdot 3$ & $11 \cdot 0$ \\
\hline
\end{tabular}

Base: 6696 pupils.

*The differences between 'weight as taken' and 'weight as eaten' were computed item by item within each food group, so the values are not equal to the differences between the averages as given in the table. This is likely to be a slight overestimate, as some measurements included containers (e.g. yoghurt pots) which could not readily be weighed separately from the wasted food itself during the weighing process in the dining room.

in sugar $(3 \cdot 0 \%)$ or snacks and confectionery (which was mainly in the form of chocolate chips in biscuits or cakes; $0 \cdot 6 \%$ ).

Girls chose more salad, fruit and milk, yoghurt and milky drinks than boys. Compared with infant aged pupils, those in the junior age group chose proportionately more portions of protein- and carbohydrate-containing foods, baked beans, desserts (including fruit-based desserts) and water. Even though these reached statistical significance, the differences were very small $(0 \cdot 5 \%)$. 
Wastage varied by type of item; lowest levels were observed for meat products, baked beans, condiments and dessert containing confectionery, and highest levels for vegetables, carbohydrate and vegetable dishes, fruit and salad. The average wastage of the food/drinks taken by pupils in 2009 was 24\%, little different from 2005 (23\%).

Table 2 shows that, on average, pupils were taking over two portions of fruit and vegetables per day (see footnote to Table 2 for definition of 'portion'). When all sources of fruit and vegetables were taken into account, across all pupils, an average of $2 \cdot 2$ portions were taken and 1.6 portions eaten. Among 'consumers' (the $93.4 \%$ of pupils who took a fruit or vegetable item), an average of $2 \cdot 3$ portions were taken and 1.8 portions eaten. About $35 \%$ of pupils consumed at least 2 portions of fruit and vegetables on a given day, and over half consumed at least 1.5 portions.

\section{Nutrient content of school lunches}

Table 3 shows the mean energy and nutrient content of school meals 'as taken' and 'as eaten' by pupils in 2009 , and 'as eaten' by pupils in 2005, and compares them with

Table 2 Number of portions of vegetables and fruit taken and eaten, by food group, primary schools, England, 2009

\begin{tabular}{|c|c|c|c|c|c|c|}
\hline \multirow[b]{2}{*}{ Food or drink } & \multicolumn{3}{|c|}{ As served } & \multicolumn{3}{|c|}{ As eaten } \\
\hline & $\%$ taking & Consumers only & All pupils & $\%$ taking & Consumers only & All pupils \\
\hline Vegetables, salad or dishes with vegetables & $74 \cdot 3$ & $1 \cdot 6$ & $1 \cdot 2$ & $70 \cdot 4$ & $1 \cdot 2$ & $0 \cdot 8$ \\
\hline Baked beans and pulses & $32 \cdot 4$ & 0.9 & $0 \cdot \overline{3}$ & $30 \cdot 6$ & $0 . \overline{8}$ & $0 \cdot 2$ \\
\hline Fruit or fruit-based desserts & $38 \cdot 5$ & $1 \cdot 5$ & $0 \cdot 6$ & $36 \cdot 1$ & $1 \cdot 2$ & $0 \cdot 4$ \\
\hline $\begin{array}{l}\text { All foods containing vegetables, salad, baked } \\
\text { beans, pulses or fruit (excluding fruit juice) }\end{array}$ & $92 \cdot 0$ & $2 \cdot 3$ & $2 \cdot 1$ & $89 \cdot 2$ & $1 \cdot 7$ & $1 \cdot 5$ \\
\hline Fruit juice & $14 \cdot 8$ & 0.8 & 0.1 & $14 \cdot 5$ & 0.7 & 0.1 \\
\hline $\begin{array}{l}\text { All food and drink containing vegetables, baked } \\
\text { beans, pulses or fruit (including fruit juice) }\end{array}$ & $93 \cdot 4$ & $2 \cdot 3$ & $2 \cdot 2$ & $91 \cdot 0$ & $1 \cdot 8$ & $1 \cdot 6$ \\
\hline
\end{tabular}

Base: 6696 pupils.

One portion of vegetable $=40 \mathrm{~g}$; one portion of fruit $=40 \mathrm{~g}$; one portion of fruit juice $=150 \mathrm{ml}$; one portion of beans and pulses $=40 \mathrm{~g}$. Fruit juice, baked beans and pulses count as maximum of one portion per day.

Composite dishes contained an average of $28 \%$ vegetables; fruit-based desserts contained an average of $40 \%$ fruit.

Proportion of baked beans to pulses as served $=0.97$.

Table 3 Mean energy and nutrient intakes from school lunches, as taken and eaten in 2009, and as eaten in 2005, infant and junior pupils, primary schools, England, compared with 2009 nutrient-based standards ${ }^{(13)}$

\begin{tabular}{|c|c|c|c|c|c|c|c|c|}
\hline \multirow[b]{4}{*}{ Nutrient } & \multicolumn{4}{|c|}{ Infants } & \multicolumn{4}{|c|}{ Juniors } \\
\hline & \multirow[b]{3}{*}{ Nutrient-based standard } & \multicolumn{2}{|c|}{2009} & \multirow{3}{*}{$\frac{\frac{2005}{\text { As eaten }}}{\text { Mean }}$} & \multirow[b]{3}{*}{ Nutrient-based standard } & \multicolumn{2}{|c|}{2009} & \multirow{2}{*}{$\frac{2005}{\text { As eaten }}$} \\
\hline & & As taken & As eaten & & & As taken & As eaten & \\
\hline & & Mean & Mean & & & Mean & Mean & Mean \\
\hline Energy $(\mathrm{kJ})$ & $1941-2145$ & 2024 & 1547 & 1621 & 2212-2444 & 2077 & 1686 & 1839 \\
\hline Energy (kcal) & $465-514$ & $483 \cdot 7$ & $369 \cdot 8$ & $387 \cdot 4$ & $529-585$ & $496 \cdot 3$ & $403 \cdot 0$ & $439 \cdot 6$ \\
\hline Protein (g) & $5 \cdot 9$ & $18 \cdot 4$ & $14 \cdot 0$ & $13 \cdot 2$ & $8 \cdot 5$ & $18 \cdot 8$ & $15 \cdot 2$ & $14 \cdot 8$ \\
\hline Carbohydrate (g) & $65 \cdot 2$ & $70 \cdot 9$ & $53 \cdot 7$ & $51 \cdot 5$ & $74 \cdot 2$ & $71 \cdot 9$ & $58 \cdot 0$ & $59 \cdot 0$ \\
\hline NMES $(g)^{*}$ & $14 \cdot 3$ & $13 \cdot 8$ & $11 \cdot 1$ & $12 \cdot 0$ & $16 \cdot 3$ & $14 \cdot 5$ & $12 \cdot 4$ & $14 \cdot 1$ \\
\hline Fat $(g)^{*}$ & $19 \cdot 0$ & $15 \cdot 9$ & $12 \cdot 4$ & $15 \cdot 7$ & $21 \cdot 6$ & $16 \cdot 6$ & $13 \cdot 7$ & $17 \cdot 6$ \\
\hline SFA $(g)^{*}$ & $6 \cdot 0$ & $6 \cdot 0$ & $4 \cdot 7$ & $5 \cdot 5$ & $6 \cdot 8$ & $6 \cdot 3$ & $5 \cdot 2$ & $6 \cdot 2$ \\
\hline Fibre (g) & $3 \cdot 9$ & $5 \cdot 0$ & $3 \cdot 6$ & $3 \cdot 2$ & $4 \cdot 5$ & $4 \cdot 8$ & $3 \cdot 7$ & $3 \cdot 6$ \\
\hline $\mathrm{Na}(\mathrm{mg})^{*}$ & 357 & $514 \cdot 9$ & $406 \cdot 7$ & $593 \cdot 1$ & 595 & $544 \cdot 8$ & $453 \cdot 5$ & $667 \cdot 1$ \\
\hline Vitamin A ( $\mu \mathrm{g})$ & 140 & $348 \cdot 5$ & $244 \cdot 9$ & $185 \cdot 8$ & 175 & $326 \cdot 7$ & $240 \cdot 8$ & $195 \cdot 6$ \\
\hline Vitamin C (mg) & $10 \cdot 5$ & $25 \cdot 3$ & $17 \cdot 9$ & $15 \cdot 9$ & $10 \cdot 5$ & $22 \cdot 5$ & $16 \cdot 9$ & $17 \cdot 2$ \\
\hline Folate $(\mu \mathrm{g})$ & 35 & $66 \cdot 5$ & $48 \cdot 4$ & $40 \cdot 0$ & 53 & $63 \cdot 0$ & $48 \cdot 4$ & $46 \cdot 0$ \\
\hline $\mathrm{Ca}(\mathrm{mg})$ & 158 & 204 & $160 \cdot 7$ & $150 \cdot 1$ & 193 & $204 \cdot 7$ & $169 \cdot 3$ & $174 \cdot 2$ \\
\hline $\mathrm{Fe}(\mathrm{mg})$ & $2 \cdot 1$ & $2 \cdot 3$ & $1 \cdot 7$ & $1 \cdot 8$ & $3 \cdot 0$ & $2 \cdot 4$ & $1 \cdot 9$ & $2 \cdot 1$ \\
\hline $\mathrm{Zn}(\mathrm{mg})$ & $2 \cdot 3$ & $2 \cdot 1$ & $1 \cdot 6$ & $1 \cdot 4$ & $2 \cdot 5$ & $2 \cdot 2$ & $1 \cdot 7$ & $1 \cdot 6$ \\
\hline \multicolumn{9}{|l|}{$\%$ of energy from } \\
\hline Proteint & - & $15 \cdot 7$ & $15 \cdot 8$ & $14 \cdot 3$ & - & $15 \cdot 8$ & $15 \cdot 8$ & $14 \cdot 1$ \\
\hline Carbohydrate & 50 & $55 \cdot 7$ & $55 \cdot 5$ & $50 \cdot 5$ & 50 & 55 & $54 \cdot 8$ & $51 \cdot 0$ \\
\hline NMES* & 11 & $10 \cdot 2$ & $10 \cdot 9$ & $11 \cdot 6$ & 11 & $10 \cdot 4$ & 11 & $12 \cdot 0$ \\
\hline Fat $^{*}$ & 35 & $28 \cdot 3$ & $28 \cdot 4$ & $35 \cdot 2$ & 35 & $28 \cdot 9$ & 29 & $34 \cdot 8$ \\
\hline $\mathrm{SFA}^{*}$ & 11 & $10 \cdot 6$ & $10 \cdot 8$ & $12 \cdot 4$ & 11 & $10 \cdot 9$ & 11 & $12 \cdot 3$ \\
\hline
\end{tabular}

NMES, non-milk extrinsic sugars.

Base (pupils): in 2009, 2482 infants and 4200 juniors - fourteen pupils could not be identified by age and were not included in the analysis; in 2005 , 3035 infants and 4023 juniors.

${ }^{*}$ Maximum permitted value: to meet the standard, mean nutrient content should be below the value shown.

tNo standard for percentage of energy to be met from protein. 
the NBS (standards relate to provision rather than consumption; they provide a useful benchmark to indicate to what extent meals 'as taken' or 'as eaten' are likely to satisfy the nutritional requirements of children). In 2009, the average meal 'as taken' met the standards for both infants and juniors for protein, non-milk extrinsic sugars (NMES), fat, SFA, fibre, vitamins A and C, folate and $\mathrm{Ca}$. Due to plate wastage, the nutrient content of meals 'as eaten' did not meet some of these standards. For example, the average meal 'as eaten' did not meet the NBS standard for fibre.

Infant meals 'as taken' met the standard for Fe, whereas junior meals 'as taken' did not, and the average meals 'as eaten' for both infants and juniors did not meet the standard for Fe. The $\mathrm{Zn}$ content of the average meals 'as taken' and 'as eaten' was below the standard for both infants and juniors. Infant meals 'as taken' and 'as eaten' exceeded the standard for $\mathrm{Na}$, although junior meals 'as taken' and 'as eaten' met this standard.

Energy 'as taken' met the standards in infants but not in juniors, and the energy content of an average meal 'as eaten' was below the standard in both groups. The average meals 'as taken' and 'as eaten' by both infants and juniors met the standards for percentage of energy from carbohydrate, NMES, fat and SFA.

Differences between 2005 and 2009 show lower levels of NMES, fat, SFA and $\mathrm{Na}$ in 2009, and higher levels of vitamin A, folate and fibre, and (in infants) vitamin C and $\mathrm{Ca}$. For example, the average infant lunch 'as eaten' had 32\% more vitamin A and over 20\% less fat in 2009 compared with 2005.

\section{Compliance of provision with food-based standards and nutrient-based standards for school food}

\section{Food-based standards}

Based on planned provision (i.e. over a full menu cycle), all schools met the standards for providing drinking water at all times, providing at least one portion of vegetable per day per child, and not providing snacks high in fat and salt (such as crisps). Over $80 \%$ of schools met the standards for providing healthier drinks such as fruit juice, extra bread without additional fat, at least one portion of fruit per day per child, at least one portion of oily fish in a three-week period, and restricting salt, condiments and confectionery.

In relation to planned provision, the standards least often met were for meat products (74\%) and starchy foods cooked in oil ( $72 \%)$; about one-quarter of schools were still serving sausages, burgers and chips more often than they should. In 2005, starchy foods cooked in fat (including chips, roast potatoes, etc.) were served on average $4 \cdot 4 \mathrm{~d} /$ week; in 2009 , this had fallen to $3 \cdot 4 \mathrm{~d} /$ week. The standard is not more than three times per week.

Only for two items, vegetables and fruit, was actual provision less likely to meet the standards than planned provision. Compliance with the fruit standard was assessed against all fruit provided at lunchtime, including fruit as served, fruit juice and fruit in fruit-based desserts (containing an average of $40 \%$ fruit). Compliance with the vegetable standard was assessed against all vegetables provided at lunchtime, including vegetables as served (raw or cooked), portions of salad and in composite dishes including vegetables (containing an average of $28 \%$ vegetables). For vegetables, this shortfall was minimal: $58 \%$ of schools met the standard fully, a further $20 \%$ provided on average at least 90 portions of vegetables per 100 pupils, and only $7 \%$ of schools provided less than 80 portions per 100 pupils. For fruit, the shortfall was greater: $12 \%$ of schools provided a portion of fruit per pupil every day; a further $22 \%$ provided at least threequarters of a portion; a further $34 \%$ at least half a portion; and about one-third of schools were providing less than half a portion of fruit per pupil per day.

\section{Nutrient-based standards}

The mean energy and nutrient content of an average school lunch were compared with the NBS for primary schools (Table 4). Over $80 \%$ of schools met the standards for protein, carbohydrate, dietary fibre, vitamins A and C, folate and Ca. Around one-half of schools met the standards for fat, Fe and $\mathrm{Zn}$. The standards met least often were for energy, NMES and Na. The energy content of the average school meal was above the standard.

The average meal provided met ten of the fourteen NBS. Over $50 \%$ of schools met nine of the fourteen standards. One hundred and seventeen (86\%) schools provided an average lunch that met between seven and ten standards, seventeen schools (13\%) met more than ten, and only two schools (1\%) provided meals that met fewer than seven standards.

Table 5 shows that when a school met a given standard, pupils were more likely to take and eat a meal that met that standard (all differences except for energy were statistically significant; $P<0.004$ ). For example, in schools that met the standard for NMES, $74 \%$ of pupils took a meal that met the standard and $80 \%$ of meals as eaten met the standard. In schools that did not meet the standard, the values were $52 \%$ and $62 \%$, respectively.

\section{Discussion}

The present survey is the first one to assess the impact of the new FBS and NBS on food and drink provided in primary schools in England, and to assess the changes in what pupils are taking and eating at lunchtime compared with 2005. The survey was carried out between February and April 2009, six to eight months after the standards became compulsory for primary schools in September 2008.

The results provide strong evidence that compared with 2005, lunchtime food provision and consumption in primary schools in England were healthier in 2009 
Table 4 Energy and nutrient content of an average school lunch compared with nutrient-based standards, based on actual provision of food and drink, primary schools, England, 2009

\begin{tabular}{|c|c|c|c|c|c|}
\hline \multirow[b]{2}{*}{ Nutrient } & \multirow[b]{2}{*}{ Nutrient-based standard } & \multicolumn{2}{|c|}{ Nutrient content of average meal } & \multicolumn{2}{|c|}{$\begin{array}{l}\text { Schools meeting the } \\
\text { nutrient-based standard }\end{array}$} \\
\hline & & Mean & SE & $n$ & $\%$ \\
\hline Energy (kJ) & $2104-2326$ & 2620 & 54 & 24 & 18 \\
\hline Energy (kcal) & $504-557$ & $626 \cdot 3$ & $13 \cdot 0$ & 24 & 18 \\
\hline Protein (g) & $7 \cdot 5$ & $23 \cdot 7$ & 0.5 & 136 & 100 \\
\hline Carbohydrate (g) & $70 \cdot 6$ & $90 \cdot 3$ & $1 \cdot 8$ & 117 & 86 \\
\hline NMES $(g)^{*}$ & $15 \cdot 5$ & $19 \cdot 0$ & $0 \cdot 6$ & 46 & 34 \\
\hline Fat $(g)^{*}$ & $20 \cdot 6$ & $21 \cdot 1$ & $0 \cdot 6$ & 73 & 54 \\
\hline SFA $(g)^{*}$ & $6 \cdot 5$ & $8 \cdot 0$ & 0.2 & 37 & 27 \\
\hline Fibre (g) & $4 \cdot 2$ & $6 \cdot 4$ & $0 \cdot 1$ & 128 & 94 \\
\hline $\mathrm{Na}(\mathrm{mg})^{\star}$ & 499 & $674 \cdot 3$ & $18 \cdot 3$ & 26 & 19 \\
\hline Vitamin A $(\mu \mathrm{g})$ & 175 & $505 \cdot 7$ & $17 \cdot 7$ & 135 & 99 \\
\hline Vitamin C (mg) & $10 \cdot 5$ & $37 \cdot 1$ & $1 \cdot 5$ & 136 & 100 \\
\hline Folate $(\mu \mathrm{g})$ & 53 & $86 \cdot 1$ & $1 \cdot 9$ & 132 & 97 \\
\hline $\mathrm{Ca}(\mathrm{mg})$ & 193 & $279 \cdot 6$ & $9 \cdot 4$ & 112 & 82 \\
\hline $\mathrm{Fe}(\mathrm{mg})$ & $3 \cdot 0$ & $3 \cdot 0$ & $0 \cdot 1$ & 65 & 48 \\
\hline $\mathrm{Zn}(\mathrm{mg})$ & $2 \cdot 5$ & $2 \cdot 7$ & $0 \cdot 1$ & 73 & 54 \\
\hline \multicolumn{6}{|l|}{$\%$ of energy from } \\
\hline Proteint & - & $15 \cdot 2$ & $1 \cdot 7$ & - & - \\
\hline Carbohydrate & 50 & $54 \cdot 3$ & $3 \cdot 8$ & 119 & 88 \\
\hline NMES* ${ }^{*}$ & 11 & $11 \cdot 4$ & $2 \cdot 7$ & 73 & 54 \\
\hline Fat $^{*}$ & 35 & $30 \cdot 2$ & $3 \cdot 8$ & 120 & 88 \\
\hline SFA $^{*}$ & 11 & $11 \cdot 4$ & $1 \cdot 8$ & 54 & 40 \\
\hline
\end{tabular}

NMES, non milk extrinsic sugars.

Base: 136 schools.

*Maximum permitted value: to meet the standard, mean nutrient content should be below the value shown.

tNo standard for percentage of energy to be met from protein.

Table 5 Percentage of meals taken or eaten that met each of the nutrient-based standards according to whether the school did or did not meet the standard, primary schools, England, 2009

\begin{tabular}{|c|c|c|c|c|c|c|}
\hline \multirow[b]{2}{*}{ Nutrient } & \multicolumn{3}{|c|}{ Meals taken that met standard } & \multicolumn{3}{|c|}{ Meals eaten that met standard } \\
\hline & $\begin{array}{l}\text { School met } \\
\text { standard (\%) }\end{array}$ & $\begin{array}{l}\text { School did not meet } \\
\text { standard (\%) }\end{array}$ & $P$ & $\begin{array}{c}\text { School met } \\
\text { standard (\%) }\end{array}$ & $\begin{array}{l}\text { School did not meet } \\
\text { standard (\%) }\end{array}$ & $P$ \\
\hline Energy (kJ/kcal) & 14 & 10 & $<0.001$ & 7 & 8 & 0.233 \\
\hline Protein $(g)^{\star}$ & 98 & - & - & 87 & - & - \\
\hline Carbohydrate (g) & 51 & 24 & $<0.001$ & 29 & 11 & $<0.001$ \\
\hline NMES (g) & 74 & 52 & $<0.001$ & 80 & 62 & $<0.001$ \\
\hline Fat $(\mathrm{g})$ & 81 & 63 & $<0.001$ & 89 & 75 & $<0.001$ \\
\hline SFA (g) & 75 & 55 & $<0.001$ & 83 & 68 & $<0.001$ \\
\hline Fibre (g) & 57 & 27 & $<0.001$ & 33 & 19 & $<0.001$ \\
\hline $\mathrm{Na}(\mathrm{mg})$ & 72 & 47 & $<0.001$ & 83 & 61 & $<0.001$ \\
\hline Vitamin A $(\mu \mathrm{g})$ & 55 & 34 & 0.004 & 41 & 20 & 0.002 \\
\hline Vitamin C $(\mathrm{mg})^{\star}$ & 73 & - & - & 56 & - & - \\
\hline Folate $(\mu \mathrm{g})$ & 73 & 42 & $<0.001$ & 51 & 25 & $<0.001$ \\
\hline $\mathrm{Ca}(\mathrm{mg})$ & 54 & 28 & $<0.001$ & 41 & 21 & $<0.001$ \\
\hline $\mathrm{Fe}(\mathrm{mg})$ & 41 & 30 & $<0.001$ & 23 & 15 & $<0.001$ \\
\hline Zn (mg) & 41 & 23 & $<0.001$ & 24 & 12 & $<0.001$ \\
\hline \multicolumn{7}{|l|}{$\%$ of energy from } \\
\hline Proteint & - & - & - & - & - & - \\
\hline Carbohydrate & 74 & 55 & $<0.001$ & 71 & 53 & $<0.001$ \\
\hline NMES & 52 & 32 & $<0.001$ & 53 & 36 & $<0.001$ \\
\hline Fat & 77 & 54 & $<0.001$ & 75 & 53 & $<0.001$ \\
\hline SFA & 68 & 46 & $<0.001$ & 67 & 45 & $<0.001$ \\
\hline
\end{tabular}

NMES, non milk extrinsic sugars; - indicates no observations.

${ }^{*}$ All schools met the standards for protein and vitamin $\mathrm{C}$.

tNo standard for percentage of energy from protein.

following the introduction of the 2008 nutritional standards ${ }^{(12,13)}$. Caterers provided more vegetables and salad, starchy foods not cooked in fat, fruit, fruit juice and fruitbased desserts, and fewer desserts without fruit, starchy foods cooked in fat and virtually no crisps and confectionery. This change in provision reflects the impact of a variety of actions undertaken by caterers and schools and their engagement with pupils and parents. 
Overall, both planned and actual provision in the majority of schools met most of the FBS. Where there were lapses these were usually relatively minor, with the exception of meat products, starchy foods cooked in fat, vegetables and fruit. Based on follow-up conversations with caterers, most of the breaches of compliance relating to meat products and starchy foods cooked in fat were caused by caterers' misunderstanding about what constituted a meat product and whether foods were deepfried in the manufacturing process. Despite the shortfall of schools meeting the standards for fruit and vegetables, pupils were taking more than 2 portions and eating 1.6 portions of fruit and vegetables at lunchtime. The wastage for these items, however, was in the range of 30-40\%; similar levels of wastage were seen in 2005. Catering providers and dining room supervisors need to find more ways to encourage pupils both to finish the vegetables served and to provide fruit more often.

The NBS proved more difficult to meet, especially for energy, NMES, SFA, Na, Fe and Zn. The energy content of the average school lunch was higher than that recommended by the standard, and relatively few schools provided meals with energy levels within the limits of the standard. Because pupils did not consume all the food taken, the average meal eaten by pupils was below the standard. It is not clear whether the low energy content of meals as eaten means that some children may not have had enough to eat at lunchtime and in consequence went hungry at this meal, or if the pupils on average have energy requirements below the NBS and that school meals are making appropriate and proportional contributions to total energy intake. In light of the need to reduce levels of obesity, more needs to be done to explore whether or not the energy content of meals taken and eaten at lunchtime is consistent with the energy needs of pupils.

Although the consumption of NMES was on average lower in 2009 than 2005, the NMES content of the average meal was above the standard (i.e. not compliant). This does not reflect, however, the shift in sources of NMES from sweetened soft drinks, non-fruit-based desserts and confectionery towards fruit juice and fruit-based desserts. Similarly, the decrease between 2005 and 2009 in the levels of SFA in the average meal consumed (Table 3) reflects a shift away from meat products, starchy foods cooked in fat and savoury snacks. Increased compliance with the FBS for meat products and starchy foods cooked in fat should result in further decreases in the future and in a greater proportion of schools being compliant with the standard for both fat and SFA.

Even though only two school caterers reported using salt in cooking, the $\mathrm{Na}$ content of an average meal was higher than the standard. This is probably due to caterers continuing to use products high in $\mathrm{Na}$ (e.g. canned products in brine, stock, etc.). It is important to note, however, that although only twenty-six schools (19\%) met the standard for $\mathrm{Na}$, the $\mathrm{Na}$ content of meals taken and eaten by pupils in 2009 was roughly one-third lower than in 2005. This reflects changes in cooking practices (i.e. caterers using recipes that have no added salt), a general reduction in the use of prepared products in school food catering as more cooking is done from scratch, and action reportedly taken by food manufacturers and wholesalers to decrease the salt content of their products. More effort is needed on all three fronts if the $\mathrm{Na}$ content of meals is to meet the standard.

Primary-school caterers were still finding it challenging to meet the minimum $\mathrm{Zn}$ and Fe content of an average school lunch. Caterers need to continue their efforts to increase the $\mathrm{Fe}$ and $\mathrm{Zn}$ content of meals by using Fe-rich and $\mathrm{Zn}$-rich foods and by modifying their existing recipes to use alternative ingredients higher in Fe and $\mathrm{Zn}$. As was the case for other nutrients, where catering provision met the standard, individual meals taken were also more likely to meet the standards (Table 5).

Children's eating habits develop at an early age and these dietary patterns are likely to persist into adolescence and adulthood $^{(16)}$. It is not reasonable to expect children to make healthy food choices (as taught in the classroom) if at the same time they are regularly being offered less healthy choices (such as burger and chips) in the dining room. By changing the range of choice to include a higher proportion of foods associated with better health (e.g. vegetables, wholegrain cereals, starchy foods not cooked in fat), it is evident that children take and eat meals at lunchtime that are more likely to meet guidelines for healthy eating. This is further supported by restrictions on access to foods high in salt, sugar and fat (e.g. snacks, confectionery, sugary drinks, starchy foods cooked in fat). The impact of the introduction of the new standards is most evident in two of the analyses presented here. First, compared with the 2005 data (collected prior to the introduction of the new standards when, for example, items such as drinks high in sugar, confectionery and snacks were not restricted), there has been a clear and substantial shift in 2009 toward healthier food provision, selection and consumption in school at lunchtime (Figs 1 and 2, Table 3). Second, where schools have met a given standard, a significantly higher proportion of pupils are likely to take and eat meals that also meet the standard (Table 5).

The survey had a number of limitations. First, compliance with the standards in law relates to planned provision over a full menu cycle (typically three weeks). This study assessed compliance for both planned and actual provision. Ideally, planned and actual provision should be very similar, but in practice may not be. Only 113 schools were able to provide the necessary menus, portion numbers and recipes to assess planned provision fully. Conversely, 136 schools provided information on actual provision, but this was based on a one-week inventory. Two FBS require assessment over either two weeks (meat products) or three weeks (oily fish). Consequently these could not be assessed in relation to actual provision. 
In addition, variations in provision over several weeks may not be reflected in a single week's inventory, so the levels of compliance with the standards could be either higher or lower than reported here. Second, it was not possible to compare the nutrient content of planned or actual provision in 2005 with 2009 because the 2005 inventory data included only a profile of the types of food and drink provided and not the total number of portions served.

Third, only $40 \%$ of recipes for main dishes were obtained and the information available on manufactured or prepared products was limited. It was necessary, therefore, to make some assumptions relating to recipe formulation and cooking methods, and this may have had an impact on the accuracy of the estimates of the nutrient content of meals provided. However, most of the information collected included detailed information on the composition of dishes, and it was therefore possible to create recipes for those that were missing or to use apparently similar recipes from other schools.

Finally, even though two typical portion weights of each item provided by schools were measured, there was, inevitably, an element of variation in portion sizes served to pupils within the same school that was not taken into account. Although this was likely to have little impact on the estimated average energy and nutrient content of meals (the nutrient content of some meals would have been overestimated if the portion size served to the pupil was smaller, or underestimated if the portion size served was larger than the portion weights measured, but this would have averaged out across all meals), it may have had a greater impact on the estimates of wastage.

\section{Acknowledgements}

Sources of funding: The survey was commissioned and funded by the School Food Trust (SFT), in collaboration with Taylor Nelson Sofres British Market Research Bureau (TNS) and Nutrition Works! Conflict of interest declaration: There were no conflicts of interest in the preparation of the manuscript. Authorship responsibilities: D.H. prepared the first draft of the manuscript. All authors carried out statistical analysis of the data and contributed to the final revisions of the manuscript. Acknowledgements: We gratefully acknowledge all the schools and pupils who took part in this survey. We would also like to thank TNS researchers (Gillian Prior, Louise Hall, Susie Smyth, Camilla Huckle), Jenny Poulter from Nutrition Works!, TNS nutritionists (Laura Scruby, Cara Monahan, Kay Dilley), SFT researchers (Jo Nicholas, Lesley Stevens) and all the TNS interviewers who helped collect the data.

\section{References}

1. Information Centre for Health and Social Care (2008) Health Survey for England 2007 Latest trends [NS]. http://www.ic.nhs.uk/statistics-and-data-collections/health- and-lifestyles-related-surveys/health-survey-for-england/ health-survey-for-england-2007-latest-trends-\%5Bns\%5D (accessed July 2010).

2. Food Standards Agency (2008/2009) National Diet and Nutrition Survey: headline results from year 1 (2008/2009). http:// www.food.gov.uk/science/dietarysurveys/ndnsdocuments/ ndns0809year1 (accessed July 2010).

3. Nelson M, Lever E, Nicholas J et al. (2009) Fourth annual survey of take-up of school lunches in England. http:// www.schoolfoodtrust.org.uk/school-cooks-caterers/reports/ fourth-annual-survey-of-take-up-of-school-meals-in-england (accessed July 2010).

4. School Food Trust (2009) School lunch and learning behaviour in primary schools: an intervention study. http://www.schoolfoodtrust.org.uk/school-cooks-caterers/ reports/school-lunch-and-learning-behaviour-in-primaryschools-an-intervention-study (accessed July 2010).

5. School Food Trust (2009) School lunch and learning behaviour in secondary schools: an intervention study. http://www.schoolfoodtrust.org.uk/partners/reports/schoollunch-and-learning-behaviour-in-secondary-schools-anintervention-study (accessed July 2010).

6. Feinstein L, Sabates R, Sorhaindo A et al. (2008) Dietary patterns related to attainment in school: the importance of early eating patterns. J Epidemiol Community Health 62, 734-739.

7. Department of Education and Employment (2001) Statutory Instrument 2000 No. 1777. Education (Nutritional Standards for School Lunches) (England) Regulations 2000. London: The Stationery Office; http://www.opsi.gov. $\mathrm{uk} / \mathrm{si} / \mathrm{si2} 2000 / 20001777 . \mathrm{htm}$

8. Nelson M, Nicholas J, Suleiman S et al. (2006) School Meals in Primary Schools in England. Research Report RR753. London: Department for Education and Skills.

9. School Meals Review Panel (2005) Turning the Tables Transforming School Food: The development and implementation of nutritional standards for school lunches. http://www.schoolfoodtrust.org.uk/UploadDocs/Library/ Documents/SMRP_Report_FINAL.pdf (accessed July 2010).

10. School Food Trust (2008) A guide to introducing the Government's food-based and nutrient-based standards for school lunches, pp. 2.1-2.4. http://www.schoolfoodtrust. org.uk/UploadDocs/Contents/Documents/sft_nutrition_ guide_aug08.pdf (accessed July 2010).

11. Department of Education and Employment (2006) Statutory Instrument 2006 No. 2381. The Education (Nutritional Standards for School Lunches) (England) Regulations 2006. London: The Stationery Office; available at http://www. opsi.gov.uk/si/si2006/20062381.htm

12. Department of Education and Employment (2007) Statutory Instrument 2007 No. 2359. The Education (Nutritional Standards and Requirements for School Food) (England) Regulations 2007. London: The Stationery Office; available at http://www.opsi.gov.uk/si/si2007/pdf/ uksi_20072359_en.pdf

13. Department of Education and Employment (2008) Statutory Instrument 2008 No.1800. The Education (Nutritional Standards and Requirements for School Food) (England) (Amendment) Regulations. London: The Stationery Office; available at http://www.opsi.gov.uk/si/si2008/pdf/uksi_ 20081800_en.pdf

14. Department for Children, Schools and Families (2010) EduBase 2. http://www.edubase.gov.uk/home.xhtml (accessed July 2010).

15. Food Standards Agency (2002) NDNS Nutrient Databank version $1 \cdot 32 \cdot 0$. London: FSA.

16. Wang Y, Bentley ME, Zhai F et al. (2002) Tracking of dietary intake patterns of Chinese from childhood to adolescence over a six-year follow-up period. J Nutr 132, 430-438. 
Appendix

\section{Food group classification for school lunches}

\begin{tabular}{|c|c|}
\hline Food group & Foods included \\
\hline Meat, poultry, fish & Beef, chicken, fish, oily fish, pork, bacon, ham \\
\hline Meat products & $\begin{array}{l}\text { Corned meat, sausages, sausage rolls, burgers (that are not economy), chopped meat, } \\
\text { kebabs, meat pies (double crust), pasties, meat puddings, meatballs, chicken/turkey } \\
\text { nuggets, coated chicken }\end{array}$ \\
\hline Protein \& carbohydrate & Pasta bake \\
\hline Protein \& vegetable & Beef and vegetable casserole \\
\hline Protein, carbohydrate \& vegetable & $\begin{array}{l}\text { Dishes made of a combination of meat/cheese/quorn, vegetable and rice/pasta/couscous/ } \\
\text { potato, cheese and tomato pizza }\end{array}$ \\
\hline Protein other & Cheese, eggs, quorn \\
\hline Carbohydrate \& vegetable & Pasta Neapolitan, pasta with vegetables, rice with vegetables \\
\hline Carbohydrate & Rice, pasta, noodles, potato, bread, couscous \\
\hline Starchy foods cooked in oil & $\begin{array}{l}\text { Chips, roast potatoes, potato waffles, croquettes, sauté potatoes, potato wedges, garlic bread, } \\
\text { fried bread, fried rice, Yorkshire puddings (including toad in the hole), pancakes, doughnuts }\end{array}$ \\
\hline Vegetables & Cooked vegetables, e.g. carrots, broccoli, peas, sweet corn \\
\hline Salad & Lettuce, cucumber, tomatoes, raw vegetables e.g. grated carrots, sweet corn \\
\hline Baked beans & Baked beans \\
\hline Sandwiches & School sandwiches including wraps \\
\hline Fruit & Fruits (canned, dried or fresh), fruit salad \\
\hline Fruit dessert & Dessert made with fruit (average of $40 \%$ fruit), e.g. fruit crumble \\
\hline Dessert \& dessert accompaniment & Biscuits, pies, cakes and pastries, puddings, sponges, custard, ice cream \\
\hline Milk, yoghurt and milky drinks & $\begin{array}{l}\text { Milk including flavoured milk and milkshakes ( } \geq 90 \% \text { milk, }<5 \% \text { added sugar or honey), } \\
\text { yoghurt, fromage frais }\end{array}$ \\
\hline Fruit juice & Fruit juice (100\% fruit juice or diluted with water, not including blackcurrant juice) \\
\hline Water & Water (still or carbonated; unsweetened, unflavoured) \\
\hline Condiments & Gravy, savoury sauces and condiments, e.g. ketchup, mayonnaise \\
\hline Non-permitted drink & Squash, soft drinks, blackcurrant juice, milkshakes ( $<90 \%$ milk, $\geq 5 \%$ added sugar or honey) \\
\hline $\begin{array}{l}\text { Non-permitted snack, confectionery and } \\
\text { dessert containing confectionery }\end{array}$ & Crisps, chocolate chip desserts, cereal bars \\
\hline
\end{tabular}

